\title{
Chemical composition and antimicrobial activity of Myristica fragrans \& Elettaria cardamomum essential oil
}

\author{
Osman Emre ÖZKAN ${ }^{*}$, Çağrı OLGUN ${ }^{1}$, Betül GÜNEY², Mahmut GÜR ${ }^{1}$, Kerim GÜNEY ${ }^{3}$, Saim
} ATEŞ ${ }^{1}$

${ }^{1}$ Kastamonu University, Faculty of Forestry, Department of Forest Industrial Engineering, TURKEY ${ }^{2}$ Ankara University, Department of Biology, Graduate School of Natural and Applied Sciences, TURKEY ${ }^{3}$ Kastamonu University, Faculty of Forestry, Department of Forest Engineering, TURKEY *Corresponding author: oeozkan@kastamonu.edu.tr

Received Date: 21.11.2017

Accepted Date: 06.09.2018

Abstract

Aim of study: The objectives in this study were to determine the chemical composition and antimicrobial activity of the essential oils from nutmeg (Myristica fragrans) and cardamom (Elettaria cardamomum).

Material and Methods: The essential oil was obtained from nutmeg and cardamom seeds through hydrodistillation method. The chemical composition of nutmeg and cardamom essential oil was analyzed by GC-MS. The antimicrobial activity of essential oil was investigated against Bacillus subtilis DSMZ 1971, Candida albicans DSMZ 1386, Enterococcus faecalis ATCC 29212, Enterobacter aerogenes ATCC 13048, Enterococcus durans, Enterococcus faecium, Escherichia coli ATCC 25922, Klebsiella pneumoniae, Listeria monocytogenes, Listeria innocua, Pseudomonas aeruginosa DSMZ 50071, Pseudomonas fluorescence P1, Salmonella enteritidis ATCC 13076, Salmonella infantis, Salmonella kentucky, Salmonella typhimurium SL 1344, Staphylococcus aureus ATCC 25923 and Staphylococcus epidermidis DSMZ 20044 with minimum inhibitory concentration (MIC) method.

Main results: GC-MS analyzes shows that $\gamma$-terpinene (19.16\%), (-)-terpinen-4-ol (14.08\%), $\alpha$-pinene $(6.75 \%)$, myristicin $(6.18 \%), \beta$-pinene $(4.85 \%)$, sylvestrene $(4.72 \%)$, elemicin $(4.68 \%)$ and safrole $(4.17 \%)$ identified in nutmeg essential oil. Also, $\alpha$-terpinyl acetate (34.55\%), eucalyptol (24.91\%), (-)-terpinen-4-ol (10.63\%), linalool (7.69\%) and neryl butyrate (6.58\%) compounds identified in cardamom essential oil as major compounds. Nutmeg and cardamom essential oil showed an antimicrobial activity against almost all test microorganisms.

Research highlights: This study suggests that nutmeg and cardamom essential oil may be useful in the medicinal application and food industry as a preservative.

Key words: Nutmeg, Cardamom, Essential oil, Antimicrobial activity

\section{Myristica fragrans ve Elettaria cardamomum uçucu yağlarının kimyasal bileşimi ve anti mikrobiyal aktivitesi}

\section{Özet}

Çalışmanın amacı: Bu çalışmanın amacı, muskat (Myristica fragrans) ve kakule (Elettaria cardamomum) 'den elde edilen uçucu yağlarının kimyasal içeriğinin ve antimikrobiyal aktivite özelliklerinin tespit edilmesidir.

Materyal ve Yöntem: Muskat ve kakule tohumlarından uçucu yağ eldesi hidro distilasyon yöntemi ile yapılmıştır. Söz konusu bu uçucu yağların kimyasal içeriği GC-MS cihazı ile analiz edilmiştir. Anti mikrobiyal aktivite deneyi Bacillus subtilis DSMZ 1971, Candida albicans, Enterococcus faecalis ATCC 29212, Enterobacter aerogenes ATCC 13048, Enterococcus durans, Enterococcus faecium, Escherichia coli ATCC 25922, Klebsiella pneumoniae, Listeria monocytogenes, Listeria innocua, Pseudomonas aeruginosa DSMZ 50071, Pseudomonas fluorescence P1, Salmonella enteritidis ATCC 13076, Salmonella infantis, Salmonella kentucky, Salmonella typhimurium SL 1344, Staphylococcus aureus ATCC 25923 ve Staphylococcus epidermidis DSMZ 20044 mikroorganizmalarına karş1 minimum inhibisyon konsantrasyonu (MIC) yöntemi ile belirlenmiştir.

Sonuçlar: GC-MS analizi sonucunda muskat uçucu yağında $\gamma$-terpinene (19.16\%), (-)-terpinen-4-ol (14.08\%), $\alpha$ pinene $(6.75 \%)$, myristicin $(6.18 \%)$, $\beta$-pinene $(4.85 \%)$, sylvestrene $(4.72 \%)$, elemicin $(4.68 \%)$ and safrole $(4.17 \%)$ ana bileşenler olarak tespit edilmiştir. Ayrıca, $\alpha$-terpinyl acetate $(34.55 \%)$, eucalyptol $(24.91 \%)$, (-)-terpinen-4-ol $(10.63 \%)$, linalool $(7.69 \%)$ ve neryl butyrate $(6.58 \%)$ bileşikleri de kakule uçucu yağının ana bileşenleri olarak tespit edilmiştir. Muskat ve kakule uçucu yağlarının deney mikroorganizmalar karşı antimikrobiyal aktiviteleri tespit edilmiştir.

Araştırma vurguları: Uçucu yağın tıp ve gıda endüstrisinde koruyucu olarak kullanılması önerilmiştir.

Anahtar Kelimeler: Muskat, Kakule, Uçucu yağ, Antimikrobiyal aktivite 


\section{Introduction}

Nutmeg and cardamom oil is generally produced by steam distillation method. Nutmeg essential oil is used as a flavoring agent in pharmaceuticals. Also, nutmeg oil is used as a fragrance component in soaps, detergents, creams, lotions, and perfumes. Nutmeg is widely used as domestic spices in cooking, in cakes and drinks. Nutmeg and cardamom have been used for carminative and stimulant and stomachic properties (Khan and Abourashed 2011). Essential oil of nutmeg have demonstrated strong antimicrobial activities (Narasimhan and Dhake 2006). Also, the cardamom essential oil show antimicrobial activity in vitro (Khan and Abourashed 2011).

Extracts of cardamom inhibited the some pathogenic strain (Kubo et al. 1991). The cardamom has been used in medicine for centuries in India and China as a carminative, stimulant, and to treat urinary, kidney diseases (Aggarwal and Kunnumakkara 2009). The subject of this study is the determination of the chemical composition and antimicrobial activity of the nutmeg and cardamom essential oil.

\section{Materials and Method Plant Material}

The mature and healthy Myristica fragrans Houtt. and Elettaria cardamomum L. obtained from Ankara, TURKEY. They were properly washed and powder before the used for the extraction of essential oil.

\section{Extraction of Essential Oil}

Essential oil was obtained by hydro distillation process using a Clevenger's type. Nutmeg and cardamom essential oil was storage in refrigerator at $4{ }^{\circ} \mathrm{C}$.

\section{GC-MS Analyze}

Similar to our previous work, GC-MS Shimadzu QP 2010 Ultra equipped with Rtx$5 \mathrm{MS}$ capillary column $(30 \mathrm{~m} \cdot 0.25 \mathrm{~mm}$; coating thickness $0.25 \mu \mathrm{m}$ ) was used for identification of essential oil components (Şener et al. 2017). Analytical conditions were injector temperature, $250{ }^{\circ} \mathrm{C}$; carrier gas Helium at $1 \mathrm{~mL} / \mathrm{min}$; injection mode: split, split ratio 1:10; volume injected: $1 \mu \mathrm{L}$ solution of the oil in hexane; and oven temperature programmed from $40{ }^{\circ} \mathrm{C}$ to 240 ${ }^{\circ} \mathrm{C}$ at $4{ }^{\circ} \mathrm{C} / \mathrm{min}$, pressure: $100 \mathrm{kPa}$, purge flow: $3 \mathrm{~mL} / \mathrm{min}$. The MS scan conditions used included a transfer line temperature of $250{ }^{\circ} \mathrm{C}$, an interface temperature of $250{ }^{\circ} \mathrm{C}$, and an ion source temperature of $200{ }^{\circ} \mathrm{C}$. GC-MS chromatograms were scanned in essential oil Wiley Data Library for identification of the constituents.

\section{Microorganism Strains}

In order to analyse the antimicrobial activity of essential oil samples, a selection of Gram negative (GN) and Gram positive (GP) strains were chosen. The ATCC, DSMZ and SL type microorganism strains were Bacillus subtilis DSMZ 1971, Candida albicans DSMZ 1386, Enterococcus faecalis ATCC 29212, Enterobacter aerogenes ATCC 13048, Enterococcus durans, Enterococcus faecium, Escherichia coli ATCC 25922, Klebsiella pneumoniae, Listeria monocytogenes, Listeria innocua, Pseudomonas aeruginosa DSMZ 50071, Pseudomonas fluorescence P1, Salmonella enteritidis ATCC 13076, Salmonella infantis, Salmonella kentucky, Salmonella typhimurium SL 1344, Staphylococcus aureus ATCC 25923 and Staphylococcus epidermidis DSMZ 20044. standard strains. Other strains, which have no standard ID information were isolated from food samples and identified at the Department of Biology, Faculty of Science, and Ankara University (Altuner et al. 2012).

\section{Antimicrobial Activity}

Antimicrobial activity test was applied according to broth microdilution (MIC) test procedure with a slight modification (Balouiri et al. 2016). The concentration of essential oil was prepared ranging from 100 $\mu \mathrm{g} / \mathrm{mL}$ to $0.195 \mu \mathrm{g} / \mathrm{mL}$ by using 96 -well micro titration plate. Each well is inoculated with an inoculum and micro plates were incubated at $37{ }^{\circ} \mathrm{C}$ for $24 \mathrm{~h}$ for microorganism strains. The MIC value is defined as the lowest concentration of oil that completely inhibits growth of the organism.

\section{Results}

The nutmeg and cardamom essential oil were analysed by using GC-MS and their 
constituents were identified by Wiley Data Library. The components, which observed more than $3 \%$, are accepted as the main components of the oils. The main components of the essential oil obtained from nutmeg and cardamom samples are given in Table 1. GC-MS analyses revealed that $\gamma$ terpinene (19.16\%), (-)-terpinen-4-ol $(14.08 \%), \quad \alpha$-pinene $(6.75 \%), \quad$ myristicin
(6.18\%), $\quad \beta$-pinene $(4.85 \%), \quad$ sylvestrene $(4.72 \%)$, elemicin $(4.68 \%)$ and safrole $(4.17 \%)$ identified as the main components of nutmeg essential oils; but, cardamom contains $\alpha$-terpinyl acetate $(34.55 \%)$, eucalyptol (24.91\%), (-)-terpinen-4-ol $(10.63 \%)$, linalool (7.69\%) and neryl butyrate $(6.58 \%)$ as the main components.

Table 1. Main components of essential oil scanning in GC-MS

\begin{tabular}{|c|c|c|c|c|c|}
\hline $\begin{array}{c}\text { Essential } \\
\text { Oil } \\
\end{array}$ & Components & $\begin{array}{l}\text { Relative } \\
\text { Area \% }\end{array}$ & $\begin{array}{c}\text { Essential } \\
\text { Oil } \\
\end{array}$ & Components & $\begin{array}{l}\text { Relative } \\
\text { Area \% } \\
\end{array}$ \\
\hline \multirow{8}{*}{ Nutmeg } & $\gamma$-terpinene & 19.16 & \multirow{8}{*}{ Cardamom } & $\alpha$-terpinyl acetate & 34.55 \\
\hline & (-)-terpinen-4-ol & 14.08 & & eucalyptol & 24.91 \\
\hline & $\alpha$-pinene & 6.75 & & (-)-terpinen-4-ol & 10.63 \\
\hline & myristicin & 6.18 & & linalool & 7.69 \\
\hline & $\beta$-pinene & 4.85 & & neryl butyrate & 6.58 \\
\hline & sylvestrene & 4.72 & & & \\
\hline & elemicin & 4.68 & & & \\
\hline & safrole & 4.17 & & & \\
\hline
\end{tabular}

According to the MIC test results, antibacterial and antifungal activity of nutmeg essential oil was found against almost all microorganism strains. The cardamom essential oil showed antimicrobial activity against microorganism strains with a MIC value ranging between 3.125 and 25 $\mu \mathrm{g} / \mathrm{mL}$. The nutmeg essential oil showed very strong antimicrobial activity against $S$. typhimurium with a MIC value of 1.562 $\mu \mathrm{g} / \mathrm{mL}$. Also, the nutmeg essential oil showed good antimicrobial activity against $B$. subtilis, $C$. albicans, E. faecalis, $E$. aerogenes, E. durans, E. faecium, E. coli, $K$. pneumoniae, L. innocua, $P$. aeruginosa, $S$. enteritidis, $S$. infantis, $S$. kentucky and $S$. typhimurium with a MIC value from 3.125 $\mu \mathrm{g} / \mathrm{mL}$ to $12.5 \mu \mathrm{g} / \mathrm{mL}$. In addition, nutmeg had weak antibacterial activity against $L$. monocytogenes, $P$. fluorescens and $S$. epidermidis and the nutmeg did not show any antimicrobial activity against $S$. aureus.

Table 2. MIC values for nutmeg and cardamom $(\mu \mathrm{g} / \mathrm{mL})$

\begin{tabular}{lcclcc}
\hline Microorganisms & Nutmeg & Cardamom & Microorganisms & Nutmeg & Cardamom \\
\hline B. subtilis & 6.25 & 6.25 & L. innocua & 12.5 & 6.25 \\
C. albicans & 12.5 & 12.5 & P. aeruginosa & 6.25 & 3.125 \\
E. faecalis & 12.5 & 6.25 & P. fluorescens & 50 & 12.5 \\
E. aerogenes & 6.25 & 3.125 & S. enteritidis & 12.5 & 6.25 \\
E. durans & 3.125 & 12.5 & S. infantis & 3.125 & 3.125 \\
E. faecium & 12.5 & 3.125 & S. kentucky & 6.25 & 3.125 \\
E. coli & 6.25 & 6.25 & S. typhimurium & 1.562 & 3.125 \\
K. pneumonia & 12.5 & 6.25 & S. aureus & - & 12.5 \\
L. monocytogenes & 50 & 12.5 & S. epidermidis & 100 & 25 \\
\hline
\end{tabular}

\section{Discussion and Conclusion}

GC/MS results of nutmeg and cardamom essential oil shows that 8 main components were identified, accounting for $64.59 \%$ of the total nutmeg essential oil and 5 main components were identified, accounting for $84.36 \%$ of the total cardamom essential oil. The main chemical compositions of the nutmeg essential oil in this study are similar to other studies. For example, Dorman 2004, 
reported that $22.0 \% \quad \alpha$-pinene, $21.5 \% \quad \beta$ pinene, $15.4 \%$ sabinene, $9.4 \%$ myristicin, and $5.7 \%$ terpinen-4-ol were the main constituents of nutmeg essential oil. Singh 2006, reported that $20.2 \%$ sabinene, $12.1 \%$ terpinen-4-ol, $10.3 \%$ safrole, $9.7 \%$ a-pinene, $6.6 \%$ b-phellandrene, and $5.9 \%$ g-terpinene were the major constituents of Indian nutmeg. Lima et al. 2012, reported that $15.0 \%$ terpinen-4-ol, $13.1 \%$ sabinene, and $11.2 \% \gamma$-terpinene were found to be the major constituents of the essential oil of Brazilian nutmeg.

The main chemical compositions of the cardamom essential oil in this study are similar to previous studies. Abo-Khatwa and Kubo 1987, reported that 1,8-cineole, aterpinyl acetate, linalool, linalyl acetate, geraniol, limonene, a-terpinene, safrole, methyleugenol, and eugenol were the main constituents of cardamom essential oil. The components and amounts of essential oil showed some differences which probably affect the genetic factors, growing location, the regional climate, herbal parts used, or the extraction and analytical methods used (Du, 2014).

In this study, the nutmeg and cardamom essential oil showed good antimicrobial activity against almost all test microorganisms. Also, other studies indicate that the essential oils of nutmeg and cardamom species have been found to have important antimicrobial activities (Kubo et al. 1991; Narasimhan and Dhake 2006).

Finally, it can be suggested that the essential oils of nutmeg and cardamom have antimicrobial activities against some gram positive and gram negative microorganisms. In view of their wide range of activity, nutmeg and cardamom essential oils may find industrial applications as a natural conservative agent in the food industries, pharmaceutical and medicinal applications.

\section{References}

Abo-Khatwa, N., Kubo I. (1987). "Chemical composition of the essential oil of cardamom seeds, Elattaria cardamomum." Proc. Saudi Biol. Soc., 10, 297-305.

Aggarwal, B. B., Kunnumakkara A. B. (2009). Molecular targets and therapeutic uses of spices: modern uses for ancient medicine, World Scientific Publishing Co, Hackensack, NJ, USA.

Altuner, E. M., Akata, I., Canlı, K. (2012). "In vitro Antimicrobial Activity Screening of Bovista nigrescens Pers." Journal of Forestry Faculty of Kastamonu University, 12(1).

Balouiri, M., Sadiki, M., Ibnsouda, S. K. (2016). "Methods for in vitro evaluating antimicrobial activity: A review." Journal of Pharmaceutical Analysis, 6(2), 71-79.

Dorman, H. D., Deans, S. G. (2004). "Chemical composition, antimicrobial and in vitro antioxidant properties of Monarda citriodora var. citriodora, Myristica fragrans, Origanum vulgare ssp. hirtum, Pelargonium sp. and Thymus zygis oils." Journal of Essential Oil Research, 16(2), 145-150.

Du, S. S., Yang, K., Wang, C. F., You, C. X., Geng, Z. F., Guo, S. S., Liu, Z. L. (2014). "Chemical constituents and activities of the essential oil from Myristica fragrans against cigarette beetle Lasioderma serricorne." Chemistry \& biodiversity, 11(9), 1449-1456.

Lima, R. K., das Graças Cardoso, M., Andrade, M. A., Guimarães, P. L., Batista, L. R., Nelson, D. L. (2012). "Bactericidal and antioxidant activity of essential oils from Myristica fragrans Houtt and Salvia microphylla HBK." Journal of the American Oil Chemists' Society, 89(3), 523-528.

Khan, I. A., Abourashed, E. A. (2011). Leung's encyclopedia of common natural ingredients: used in food, drugs and cosmetics, John Wiley \& Sons.

Kubo, I., Himejima, M., Muroi, H. (1991). "Antimicrobial activity of flavor components of cardamom Elettaria cardamomum (Zingiberaceae) seed." Journal of agricultural and food chemistry, 39(11), 1984-1986.

Narasimhan, B., Dhake, A. S. (2006). "Antibacterial principles from Myristica fragrans seeds." Journal of medicinal food, 9(3), 395-399.

Singh, G., Marimuthu, P., Heluani, C. S. D., Catalan, C. (2005). "Antimicrobial and antioxidant potentials of essential oil and acetone extract of Myristica fragrans 
Houtt.(aril part)." Journal of Food Science, 70(2).

Şener, N., Özkinali, S., Gür, M., Güney, K., Özkan, O. E., Khalifa, M. M. (2017). "Determination of antimicrobial activity and chemical composition of pimento \& ginger essential oil." Indian Journal of Pharmaceutical Education and Research, 51(3), S230-S233. 